\title{
Macro, mezzo and micro-level analysis of gender responsive budgeting in Rwanda
}

\author{
Siringi Elijah Mirwoba \\ Department of Finance, School of Finance and Banking, Kigali Rwanda. E-mail: drsiringi@rediffmail.com. \\ Tel: +250785291458 or +254724971445 . \\ Accepted 31 May, 2012
}

\begin{abstract}
This study focuses on Gender Responsive Budgeting (GRB) as an alternative approach for equitable allocation of gender resources for men, women, boys and girls in Rwanda. This study uses purposive sampling technique to identify 115 respondents from institutions and gender machineries in Rwanda. Face to face interviews and focus group discussions were utilised to gather primary data base. The empirical results indicated that Rwanda government has integrated and adapted GRB methodology into national accounting system to allocate gender resources. This study found that there are distortions of information and inconsistency in preparation of gender budget statements as well as imbalance of allocation of gender resources at micro-level in Rwanda. This study suggests the need for capacity building to strengthen skills of economists, planners and budget officers bestowed with the obligation of engendering the national budget. This study further opines that the government of Rwanda should set benchmarks to guide allocation of gender resources at macro, mezzo and micro-level.
\end{abstract}

Key words: Gender responsive budgeting, national budget, gender equality, impact.

\section{INTRODUCTION}

National budgets fail to take into account the fact that men and women have different roles, responsibilities and resources in society (Elson, 2002). Whereas, there is a general practice that conventional economists do not account for and integrate unpaid care work into Gross Domestic Product (GDP) calculations, this scenario demonstrates a gender dilemma on the part of the conventional economics that poses a serious limitation when it come to understanding how gender relations permeate and structure economic activity in markets (Sharp, 2007b). Since the birth of Keynesian thought that look at economics as a means of wealth distribution by the so called "rational economic man" the "homoeconomicus", conventional conceptual frameworks and statistics used to design macro-economic policy have been and continue to be gender blind (Sharp and Vas Dev, 2004). More of the women's work than men's work is not counted by the national economic statistics because a great deal of it is not market oriented (ILO 2006). Realistically, this kind of unpaid work behind the curtains is a subsidy of the sort to the productive and paid economy (Budlender et al., 2002). Mainstream economic theory fails to recognise that women contribution to the economy is significant but systematically underestimated; there is an unpaid care work economy in which women do most of maintaining the labour force and keeping the social fabric in good order, maintaining social cohesion, civic responsibility and good neighbourliness (Ichii, 2010). As a result, there have been all sorts of exploitations mounted to females by the masculine society-exploiting silent or inexistence of legal and institutional loopholes that assume unitary society where men and women are on the same footing (Villagomez, 2004).

Whereas, many governments have ratified international gender instruments, such as CEDAW (Convention on the Elimination of ALL forms of Discrimination against Women), gender inequality persist (Ngone, 2002). In Rwanda for instance, the crosscutting nature of gender issues are highlighted in all the national legal and planning frameworks including the vision 2020, the EDPRS (Economic Development and Poverty Reduction Strategy) and the national gender policy of the 
government of Rwanda (EDPRS, 2008 to 2012); however (Sodani and Sharma, 2008) indicates that, adaptation of gender responsive budgeting into the national accounting systems remains a challenge. Besides, there is lack of indepth and rigorous empirical and theoretical studies that examine and analyse effectively and efficiently on gender issues, in particular, gender responsive budgeting in Rwanda. When performing the gender budget exercise, one would typically ask questions such as: How does Gender Budget Statements (GBS) influence distribution of resources and allocation between women and men and among different social groups in Rwanda?; What are the implications in the short and long term, for the gender distribution of resources at micro, mezzo and macro levels in Rwanda?; and; how does policy affect gender norms and roles?. This study was guided by the following specific objectives: assessing the level of adaptability of gender responsive budgets into sector-wise budget plans in Rwanda; determining how Gender Budget Statements (GBS) influence distribution of resources between women and men and among different social groups in Rwanda? and to analyse the implications of gender responsive budgeting on resources allocation of Rwandan economy. This research study makes a contribution by unveiling knowledge that advance literature on the level of adaptation of GRB into national accounting system of Rwanda and; therefore, builds a framework with which a national gender responsiveness culture can evolve within the realms of Rwandese economy. This article is divided into four distinct sections. The first section captures the introduction and the conceptual framework. The second section provides information on research methodology adopted for the study. The third section focuses on study analysis and discussion of empirical research results. Finally, the article ends with conclusion and recommendations in final section.

\section{Conceptual framework of the study}

This research study provides a comprehensive understanding of gender responsive budget (GRB) initiatives and how the government of Rwanda is integrating the sector-wise gender budget plans into her national accounting system. GRB initiatives are intended to afford a mechanism by which governments, in collaboration with lawmakers, civil society groups, donor and other development agencies, can integrate a gender analysis into fiscal policies and budgets (Elson, 2002). At conceptual level of this study, we trace the interplay of variables of GRB and how these variables interact once the integration of the gender perspectives have been accounted and implemented in national accounting system in Rwanda. Besides, the conceptual framework unveils information on gender responsive budgets can be utilized as a pivotal tools to assess budgetary performance and impact in a country (Barnett and Grown 2004). In addition, the conceptual framework provides a perspective of the GRB preparation tools that the study attempts to assess sector-wise: micro, mezzo and macro level to determine its impact in Rwandan economy. The GRB tools adopted by the Ministry of Finance and Economic Planning (MINECOFIN) by Rwanda government have been made mandatory for pilot sectors ministries (Health, Agriculture, Education and Infrastructure) and therefore, it is used as preparation budget tools for GRB integration process into national accounting system (Figure 1).

\section{RESEARCH METHODOLOGY}

This study adopts descriptive survey research design. This research design was deemed suitable because the design presents oriented methodology to investigate the population by selecting samples to analyse and discover occurrences. It will also provide numeric description of some parts of the population under study and describe and explain events as they are (Mukhopadhyay, 2002). Moreover, a combination of participatory techniques was used to obtain, analyse and report on both primary and secondary data. The main methodology comprises of the following:

\section{Extensive reviews of literature, statistical databases and abstracts}

Extensive reviews of literature, statistical databases and abstracts were undertaken to establish the most pressing and relevant Gender Responsive Budgeting (GRB) policy analysis and integration challenges into Rwandan accounting systems. The documents analyzed include poverty reduction strategies (EDPRS) and monitoring reports; sector policies and plans, budgets and implementation reports; diagnostic and evaluation studies; UNDP's human development reports and World bank's World development report; African development statistical abstract; and Statistical surveys produced by the National Institute of Statistics. Current curriculum context of gender and economic studies at the School of Finance and Banking (SFB), National University of Rwanda (NUR) and Kigali Institute of Education (KIE) were reviewed.

\section{The population, sample and sampling procedure}

The population of this study comprises of institutions and gender machineries in Rwanda that were subjected to stratification to categorize them as per the functionary obligations that each institution bestow to the Republic of Rwanda. A list of these institutions was acquired from the ministry of gender and family planning government of Rwanda. The first category is the Economic Policy Management Institutions for Gender that include; Ministry of Finance and Economic Planning government of Rwanda (MINECOFIN); National Institute of Statistics of Rwanda (NISR); Central Bank of Rwanda (BNR); and Development Bank of Rwanda (BRD).The second category is capacity building institutions on gender issues namely: School of Finance and Banking, Kigali Institute of Education and; National University of Rwanda. The third category of institutions in this study population is Economic Policy Research Institutions. Under this category one institution was identified, namely, Institute of Policy Analysis and Research of Rwanda. The fourth category of institutions includes those that were key sectoral Institutions mainstreaming gender programmes in Rwanda namely, Ministry of Education (MINEDUC), Ministry of Infrastructure (MIFOTRA), Ministry of Health $(\mathrm{MOH})$, Ministry of Agriculture (MINAGRI), Ministry of Trade and Commerce (MINICOM). 


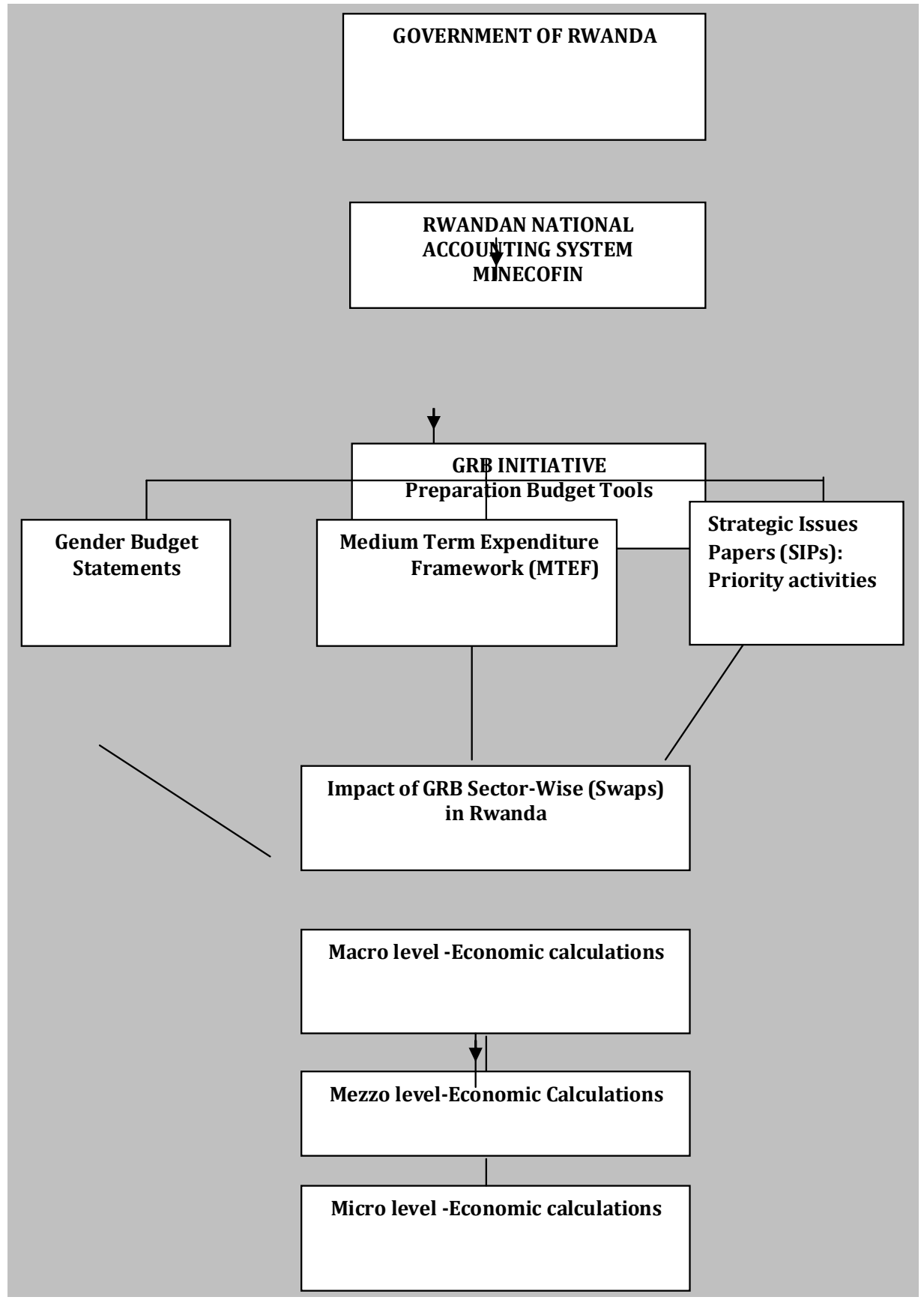

Figure 1. Conceptual Approach for integration of GRB into national accounting System in Rwanda

The fifth category of institutions in this study population is gender mainstreaming agencies namely: Ministry of Gender and family Planning (MIGEPROF) and Gender Monitoring Office (GMO).The sixth Category of Institutions is Development Partners on gender Issues namely: UN Women; UNDP; European Union ; World Bank; AFDB; and; UN-ECA/EASRO.

To obtain the sample size of this study proportionate stratified sampling technique was utilized to select the respondents from each category of the institutions and gender machineries in Rwanda such that a total of 115 respondents were arrived at. Table 1 provides the list of stakeholder groups or categories, institutions that fall under each category and the proportionate sample size for each category.

\section{Interviews and discussions}

Interviews and discussions with policy makers and development partners, and regional organizations working in areas related to GRB were conducted. Besides face to face interviews and Focus Group Discussions (FGD) with key officials of MINECOFIN and UN Women formed critical sources of primary database. Secondary 
Table 1. Sample size of the study.

\begin{tabular}{llc}
\hline Stakeholder group & Institution & $\begin{array}{c}\text { Number of target } \\
\text { individuals }\end{array}$ \\
\hline Economic Policy Management institutions & MINECOFIN; NISR; BNR; BRD & 20 \\
Capacity Building Institutions & SFB; KIE, NUR & 10 \\
Economic Policy Research & IPAR & 5 \\
Key Sectoral Institutions & MINAGRI;MINICOM; MINEDUC; MOH; MINELA; MIFOTRA & 30 \\
Gender Mainstreaming Agencies & MIGEPROF; Gender Monitoring Office(GMO) & 10 \\
Development Partners & UN Women; UNDP; European Union; World Bank; AFDB; UN- & 40 \\
& ECA/EASRO; & $\mathbf{1 1 5}$ \\
\hline
\end{tabular}

\begin{tabular}{|c|c|c|c|c|}
\hline \multicolumn{1}{|c|}{} & \\
\hline Ministry Gender Resources Allocation Rw. \\
Rwf. In Billions
\end{tabular}

Figure 2. Comparison of ministries gender resources in relation to National Budget 2010/2011. Source: Field data.

data were gathered from government publications, UN women Offices, MINECOFIN, Ministry of Gender and Family promotion Government of Rwanda District Development Offices for gender, National institute Statistics of Rwanda, Institute of Policy Analysis of Rwanda, Gender Monitoring Office Rwanda

\section{Focus group discussions}

Focus group discussions with policy makers and analysts was undertaken through regular dialogue sessions with sectoral agencies, MINECOFIN, research, academia and civil society. Besides, face to face briefs with UNDP, MINECOFIN and UN women policy helped to unveil information relating to GRB in identifying innovations and good practices, as well as challenges and lessons to inform the GRB programme design and policy makers.

\section{Data analysis and presentation}

The content analysis methodology is applied in this study. The major reason being that information and data for this study was obtained from relevant published and unpublished documents, circulars, reports and publications of related ministries and NGOs. Newspapers and online information is also used. It may be mentioned here that gender responsive budgeting is an ongoing process and a new phenomenon in Rwanda. So, content analysis is taken as one of the methods to find out the current scenario of GRB initiatives and challenges with a specific focus on its implementation. The other methodology is descriptive statistics that is utilized in presenting analysis of research data. Besides, tables, graphs and charts are also used to present empirical research results.

\section{MACRO-LEVEL ANALYSIS OF GRB ADAPTABILITY PROCESS IN RWANDA}

Our study made an attempt to analyse the priority sectoral activities that were funded at macro-level by the government of Rwanda during the financial year 2010/11. The information reflected in the bar graph below, shows a comparison of the total national budget in relation with gender resources allocated by the four piloted sector ministries. This study reveals in Figure 2 that the ministry 
Table 2. Ministry of Education and Resources Allocation -2011/2012

\begin{tabular}{|c|c|c|}
\hline Gender sub-programmes/initiatives & Gender output & $\begin{array}{c}\text { Allocated development } \\
\text { budget (Rwf) }\end{array}$ \\
\hline Student by books by gender ratio & Streamline ratio of student by books by gender. & $6,737,080,093$ \\
\hline Health and sanitation in 9YBE schools & 90 Counselors trained on health and sanitation & $21,082,590$ \\
\hline Gender sensitive materials & $\begin{array}{l}\text { Provide Gender sensitive materials to } 1000 \text { schools - } \\
\text { Sanitary towers to girls }\end{array}$ & $350,000,000$ \\
\hline \multirow[t]{2}{*}{$\begin{array}{l}\text { Sensitize and train teachers and parents } \\
\text { to promote participation of girls in } \\
\text { science and technology streams }\end{array}$} & $\begin{array}{l}\text { Three schools by district teachers and parents committee } \\
\text { sensitized to promote participation of girls in science and } \\
\text { provide technologies;-Computers/.Laptops }\end{array}$ & $69,885,400$ \\
\hline & Total Allocation (Rwf) & $7,178,048,083$ \\
\hline
\end{tabular}

Source: Gender Budget Statement MINECOFIN 2011/2012.

of agriculture allocated the highest amount of resources targeting gender programmes that translates to about $32 \%$ of the total national budget while; the ministry of infrastructure allocated the least gender resources of about $4 \%$ of the total national budget.

\section{Ministry of education and GRB integration process}

In 2011/2012 fiscal year, the Ministry of Education (MINEDUC) rolled out various programmes targeting boys and girls. These include: Student by books by gender ratio; Health and sanitation in 9YBE schools; Gender sensitive materials and; promotion of participation of girls in science and technology streams. The study analysis noted that MINEDUC programmes are gender sensitive programmes and indeed resources have been set aside to finance them. For instance, the programme targeting to achieve the ratio of student by books by gender, the study notes that the ministry plans to purchase and supply a total of 1,200,000 text books to Pre -primary, primary, and secondary (Upper and lower) schools by March 2012.The study established that MINEDUC has allocated resources worth Rwf. $6,737,080,093$. Another initiative by the ministry is strengthening health sanitation facilities in 9YBE schools. In this initiative, the ministry intends to develop guiding documents on health and sanitation, train the 90 counselors on health and sanitation, and finally provide sanitary towers to 1000 school to improve hygiene and attendance of girls' pupils in schools. The total allocation of resources from the MINEDUC for these initiatives is Rwf. 371,082,590. The third initiative by the ministry of education is a programme that is intended to sensitize and train teachers and parents to promote participation of girls in science and technology streams. In Rwanda, it is felt that boy's out- number girls in science and technology courses at post basic level including in TVET. There remains a divergence in the subjects studied by boys and girls: in 2009 only $36 \%$ of pupils in maths-physics were girls. With this background, MINEDUC has introduced this initiative. The MINEDUC allocations is intended for developing training modules and materials as well as for training teachers in three schools per district in Rwanda and; purchase 100 computers/laptops for the schools. The Ministry resources allocation is Rwf. 69,885,400 (Table 2).

\section{Ministry of education and resources allocation 2010/2011}

From the study analysis on gender programmes in the ministry of education and resources allocation for the fiscal year 2011/2012 as shown in Figure 4, it is noted that there is a disparity of resources allocation across the board. Resources allocated for purchase of books to improve the students by book by gender ratio is shown to have been allocated the highest amount of resources. This study also notes that the training of counselors on health and sanitation received the least allocation of resources. Whereas the gender initiatives by the MINEDUC may impact positively on mainstreaming GRB in public allocation through the national budget, this study analysis shows that there is need for more resources to be allocated to all sub- programmes in general (Figure 3).

\section{Gender budget programme in the ministry of agriulture-2011/2012}

Rwanda is an agrarian economy with over $80 \%$ of the population relying on agriculture and related activities for their livelihoods. The country's population is estimated at 10.4 million (2010 mid-year projection) and about $53 \%$ is female. Rwanda's population density of 373 per square kilometre is one of the top ten in the world. The country has made remarkable progress from a destructive genocide of 1994 to peace and development. Rwanda's vision 2020 , finalised in 2002 , is the key socio-economic 


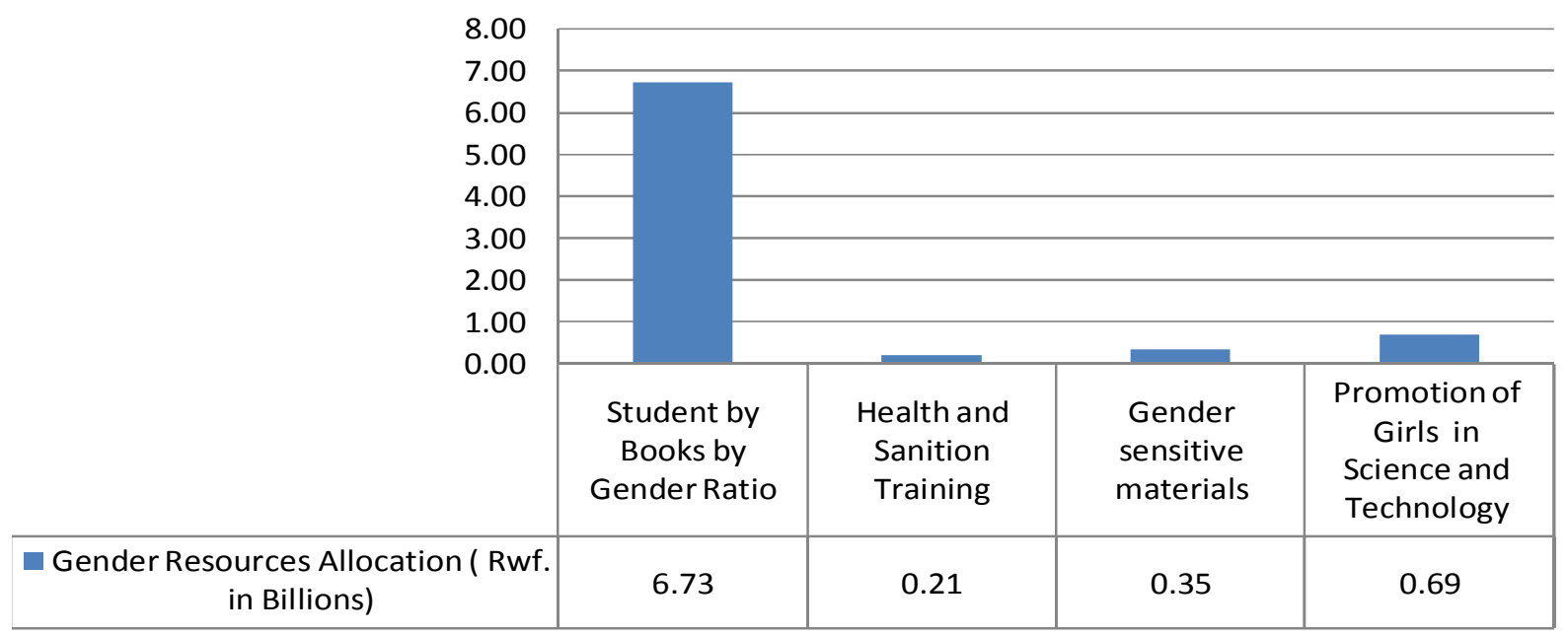

Figure 3. Analysis of Gender resources allocation 2011/2012 (Rwf. In Billions). Source: Gender budget statement MINECOFIN 2011/2011.

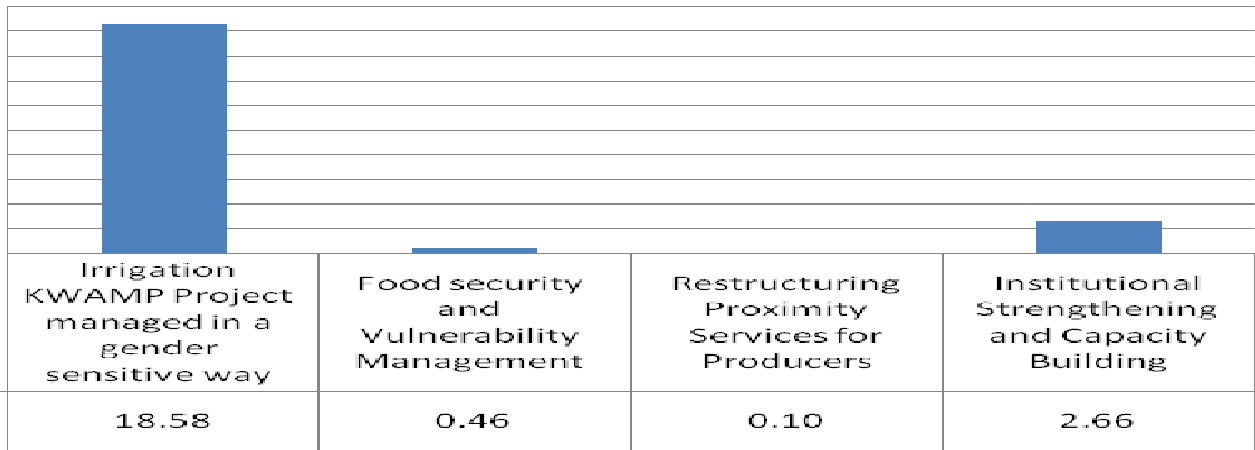

Figure 4. Minagri gender resources allocation 2011/2012 (Rwf. In Billions). Source: Gender budget statement MINECOFIN 2011/2012.

policy document on which all national and sectoral policies and strategies are based. The bold targets of the vision 2020 include increasing per capita GDP from USD 230 in 2000 to USD 900 in 2020, reducing the proportion of the poor from $60 \%$ of the population to $25 \%$. The Economic Development and Poverty Reduction Strategy (EDPRS 2008 to 2012) provide a medium-term framework for increasing economic growth and reducing poverty. Using 2007 as the baseline year, EDPRS aims to reduce general poverty from 57 to $46 \%$, extreme poverty from 37 to $24 \%$ and $\mathrm{WHH}$ poverty from 60 to $48 \%$.

Despite the huge number of people involved in agricultural related activities, the sector contributes less than $40 \%$ to GDP. Although gender equity and equality is a right as enshrined in the Rwanda constitution, there are intrinsically related factors contributing to the poor agriculture performance, major one being the gender disparities. The agriculture sector is worked mainly by poor women $(86 \%)$ with lowest levels of schooling and highest rates of illiteracy (23.3\%). As a result women remain in the subsistence agriculture, they receive low prices for their products due to lack of market intelligence, they lack capacities to participate in agribusiness and are employed in lowly paid positions in secondary agriculture. All these result in a vicious cycle of poverty that transcend generations; $30 \%$ of the country's households are female-headed and most of them are very poor The increasing number of female headed households in the rural areas makes agriculture vulnerable to any type of shock events because women rarely have asset stocks nor financial savings because of their foundation of being illiterate, poor and stereotyped to be subordinate to male counterparts be it at household, community and governance structure levels; women contribute immensely to the agriculture value chain by providing labour for planting, weeding, harvesting and processing in addition to reproductive activities and community work. They also produce and sell vegetables from home gardens or forest products and the income obtained is mainly used on meeting family food, health and education needs. However, this contribution is rarely 
recognised at household or in national statistics. The ministry of agriculture recognises the critical role played by women and has launched agriculture gender strategy in 2011 to mitigate the challenges facing women. Moreover, the gender gaps have been identified in this sector and some programmes have been initiated.

This study notes that in the Ministry of Agriculture (MINAGRI), the gender budget allocation targets on one major programme entitled "Intensification and Development of Sustainable Production" during the fiscal year 2011/2012. Under this programme there are four sub-programmes: Irrigation development; Food security and Vulnerability management; Restructuring proximity services for producers and; Institutional strengthening and capacity building development and rehabilitation of radical and progressive terraces on hillsides and support to farmers who own land to form cooperatives seek to benefit the crop intensification programme. This study analysis shows that the work of women is absolutely essential towards food and nutrition security, both at the household and the national level. Women are responsible for the production of many staple crops, as well as certain crops that contribute to nutrition security. These include beans, which provide most of the protein consumed in Rwanda, and fruit and vegetable gardens, which are also essential for a balanced diet. Much of the profits of farming go to male members of the household who produce cash and marketable crops. However, there is a lack of gender interventions related to water and soil conservation. Women are still few in water conservation technologies (irrigation, environmental sciences, rural engineering). To mitigate these challenges the ministry of agriculture has embarked irrigation development with the initiation of KWAMP project managed in a gender sensitive way. In this sub-programme the government of Rwanda through the ministry of agriculture is assisting farmers to organize themselves into cooperatives and sensitize them on the importance of having female involvement in cooperative societies. In addition, the government is committed to sensitize farmers and local authorities on using effective, sustainable soil conservation and water management techniques to improve food security. The ministry has allocated resources through gender sensitive budget amounting to Rwf. 18,581,654,644. This study notes that this subprogramme has been allocated the highest resources compared to other gender sub-programmes. On institutional strengthening and capacity building, the government has allocated Rwf. 2,658,228,518. This allocation is meant to enhance knowledge and skills on how to mainstream gender in policies, programmes, projects and activities throughout the ministry and its related agencies. Besides, resources allocated shall help to ensure that gender sensitivity in accountability systems is strengthened. The study notes that despite of Rwanda having one of the highest female participation in parliament in the world, there is limited participation of women in agricultural structures. Additionally, at the decentralized level, there are concerns of limited partnerships and coordinating mechanisms for promoting gender inclusiveness at all levels. It is also expected that follow-up on gender and democratic governance project and gender responsive budgeting programme through the ministry shall be mainstreamed.

Within the gender budget statement restructuring proximity services for producers sub-programme was reflected in agriculture sector for the period 2010/2011. The position of the ministry of agriculture is that the programme is critical as women contribute greatly to agricultural production in general and subsistence crops in particular. It was felt however, that they benefit less from agricultural extension services compared to men. Moreover, ministry indicates that the involvement of women in training workshops is very limited compared to men; the same applies to women agricultural extension agents. The low participation of women in extension and training sessions can be explained by the fact that they are often forced to ask for permission from their husbands; and also because of their multiple roles that make them unavailable.

Furthermore, the location of training workshops is often quite far from their homes, which does not encourage them to attend. This study established this concern and found that the ministry has plans to allocate an amount of Rwf. 100,000,000 to set up District agricultural platforms, Zonal agricultural advisory service teams and a National agricultural advisory service committee to up to date gender specific needs assessment for allocation of advisory services at district level. On food security and vulnerability management sub-programme, the ministry has moved in pro-active manner to initiate this programme which targets farmers, particularly women, to be trained in the production of improved banana, mushroom cultivation and other food crops to strengthen food security status in Rwanda. The ministry has allocated Rwf. 21,385,589,570 as illustrated in Table 3.

\section{GRB adaptability level in the ministry of health}

In Rwanda, there are insufficient midwives, nurses, midwifery experts and instructors in schools of nursing, and limited equipments and teaching materials in schools and clinical placements. These challenges impact negatively on provision of service delivery in health sector. It is also noted that there is gender imbalance reflected among the workers. To ameliorate these challenges the ministry of health has plans to increase the number of midwives and nurses, supply training materials to nursing schools and subsidize health services. The ministry through the gender budget statements allocates resources amounting to RWF $137,899,832$. It is expected that the number of qualified midwives is increased from 300 to 600 by end of fiscal 
Table 3. Ministry of Agriculture and Resources Allocation 2011/2012.

\begin{tabular}{lll}
\hline Gender sub-programme/initiative & Gender situational analysis & \multicolumn{1}{c}{$\begin{array}{c}\text { Allocated development } \\
\text { Budget (Rwf) }\end{array}$} \\
\hline $\begin{array}{l}\text { Irrigation-KWAMP project managed in } \\
\text { a gender sensitive way }\end{array}$ & $\begin{array}{l}\text { There is a lack of gender interventions related to water } \\
\text { and soil conservation. Women are still few in water } \\
\text { conservation technologies (irrigation, environmental } \\
\text { sciences, rural engineering). }\end{array}$ \\
$\begin{array}{ll}\text { Food security and vulnerability } \\
\text { management }\end{array}$ & $\begin{array}{l}\text { Farmers, particularly women, are trained in the production } \\
\text { of the banana staple and food security crop and their food } \\
\text { security status is improved. }\end{array}$ \\
$\begin{array}{ll}\text { Restructuring proximity services for } \\
\text { producers }\end{array}$ & $\begin{array}{l}\text { Improved access to advisory services for crops and } \\
\text { livestock and access and use of high quality planting } \\
\text { materials of food crops for men and women - done } \\
\text { through support to PSTA Il project. }\end{array}$ \\
$\begin{array}{ll}\text { Institutional strengthening and capacity } \\
\text { building }\end{array}$ & $\begin{array}{l}\text { Follow up gender and democratic governance project and } \\
\text { gender responsive budgeting programme }\end{array}$ \\
& Total resources allocation (Rwf.) \\
\hline
\end{tabular}

Source: Gender Budget Statement MINECOFIN 2010/2011.

year 2011; the number of midwifery experts and instructors increased from 5 to 12 in each nursing school and; each nursing school in Rwanda is equipped with a library with training equipment in the practical room and clinical placement.

The second gender programme is promoting financial accessibility to health services that will enhance subsidization of health services. The growing literature indicates that women headed households are part of the most vulnerable families and often do not benefit from subsidization of health services. The ministry health has allocated resources amounting to RWF 711,622,000. This allocation is geared towards developing a user gender responsive data bank and provides support accordingly. This study noted that the percentage of female headed household benefiting from assistance shall increase by $2 \%$.

The health equipments sub programme in the ministry of health is a gender sensitive programme. This study established that the programme is intended to reduce high rate of maternal mortality from $750 / 100,000$ to $600 / 100,000$, and carry out a rehabilitation of maternities in district hospitals. The ministry has allocated resources to the tune of Rwf. 450,000,000, for the construction of 60 health posts. This study noted that there is limited number of ambulances in each district which negatively impact on accessibility to women during delivery. To strengthened and improve referral system that efficiently responds to obstetric and neonatal complications at all levels of the healthcare system the ministry of health through gender sensitive budget has allocated resources amounting to Rwf. $1,800,000,000$. It is expected that 60 ambulances shall be purchased and supplied to respective district hospitals.

Poverty coupled with under development brought about by 1994 genocide to Rwanda has contributed largely to malnutrition. With this realisation, the ministry of health has put in place a gender sensitive sub- programme to fight against malnutrition in Rwanda. The rationale behind this programme is based on the fact that poverty dynamics and social and cultural attitudes, women and children are more vulnerable to malnutrition than men. Growing literature indicates that currently, nutritionrelated services are not able to combat the high levels of nutrition. The ministry of health through gender sensitive budgets has allocated Rwf. 64,310,000 during the fiscal year 2010/2011. The resources will be utilised to reduce the rate of under- five years stunted children from 45 to $35 \%$ by 2011 .Besides, the allocation shall enhance provision of food supplements and micro-credit to vulnerable population (Table 4). Malaria is one of the pandemic diseases that claim the lives of many persons more especially in the Sub-African countries, Rwanda being inclusive. The government Rwanda through the ministry of health has embarked on pro-active polices to mitigate the negative impact of malaria to the general population and in particular expectant mothers and children (Figure 5).

The ministry through the sub-programme entitled "Fight against Malaria" distributes "long lasting insecticide treated nets" (LLINs) at the community level. During the fiscal year 2010/2011, the ministry allocated resources worth Rwf. 9,898,853,985 for the programme. This study noted that from the ministry allocations a total of 432,557 LLINs shall be distributed free of cost to pregnant women in 2010 and 444,669 LLINs in 2011. 
Table 4. Ministry of Health and Resources Allocation 2010/2011.

\begin{tabular}{lc}
\hline Gender sub-programmes/initiatives & Resources allocation (Rwf) \\
\hline Increase the number of midwifes and nurses & $39,200,000$ \\
Training materials to nursing Schools & $98,699,832$ \\
Subsidization of Health Services & $711,622,000$ \\
Rehabilitation of District Maternity Hospitals & $450.000,000$ \\
Purchase and supply of Ambulances & $1,800,000,000$ \\
Procure and distribute LLINS to fight Malaria & $9,898,853,985$ \\
To fight Malnutrition & $64,310,000$ \\
Total Resources (Rwf.) & $13,062,685,817$ \\
\hline
\end{tabular}

Source: Gender Budget Statement MINECOFIN 2010/2011.

\section{GRB analysis at mezzo-level in Rwanda}

In line with the government of Rwanda's policy on gender and in her commitment in mainstreaming GRB at the mezzo level, provinces in Rwanda play a key role in overseeing and monitoring districts to ensure that the gender budget resource allocations are efficiently utilized. In order for the provinces to undertake this responsibility they have been allocated a monitoring budget through the national budget which facilitates them to carry out their monitoring activities.

The bar graph above shows the gender monitoring budget allocations to each province. The Eastern province stands out as one of the provinces with the highest resource allocation (177.3 Millions) followed by the Southern (13 Million), Western (8.8 Millions) and Northern becomes the last in terms of gender monitoring resource allocations (4.1 Millions). The Eastern province gives priority to political representation and all political appointees must be gender based, part of the gender monitoring budget allocation is to ensure that all people have access to quality health services. On the education sector the Eastern province is concerned with the universal education targeting both boys and girls through the number of competition exams and grants provided both to boys and girls. In addition the Eastern province is committed on improving the living conditions of the people and more especially the vulnerable groups. In this regard the province makes a follow up to understand how the gender budget allocations targeting the vulnerable groups have been utilized.

In the Southern province the research establishes that gender balance is considered in planning but there are challenges in the involvement of women in the implementation of projects programs as planned. Thus, the entire monitoring budget allocations are to ensure in all Districts (8) Gender Responsive Budget is implemented. On the other hand, the western province gives farming a priority and all the gender monitoring resource allocation is to ensure that farmers' cooperatives are working and devolved to the level of the sector (Umurenge) for the benefit of all farmers. Finally, the Northern Province with the least gender monitoring budget allocation gives priority to political representation in terms of men and women in various levels of decision making, and enhances the number of women in senior management positions in cooperatives. Besides the resources for monitoring is to ensure that all gender related activities are implemented as planned and gender activities in districts are coordinated regularly.

\section{GRB analysis at micro-level and its impact in Rwanda}

The last objective of this study was to address the integration and adaptability of GRB into sector-wise budget plans. This objective could enable the researcher to assess to what extent GRB integration process has impacted on the national accounting system of Rwanda's economy. According to the information available from the Ministry of Finance and Economic Planning (MINECOFIN) in Rwanda, the integration and adaptability of GRB methodology into district sector-wise budget plans is place. It is mandatory for the districts in each fiscal year to reflect gender dimension in their gender situational analysis when preparing the gender budget statements for the four piloted GRB piloted Ministries.

In this study micro-level analyses of 15 districts have been captured. This study noted that there are several challenges of distortion of information in preparation of gender budget statements at micro-level. This aspect has been noted while examining closely the format and gender situational analysis as well as activities intended for allocation resources. To clear this doubt, the researchers made an attempt to contact and discuss his issue with officials from MINECOFIN. The officials were skeptical about this issue and quickly pointed at lack of skills and techniques on the part of planners and budget officers who are bestowed the obligation to carry out the gender situational analysis and incorporate them into the gender budget statements. The officers informed the researchers that the ministry is aware of this dilemma and have identified school of finance and banking through the department of economics in the fiscal year 


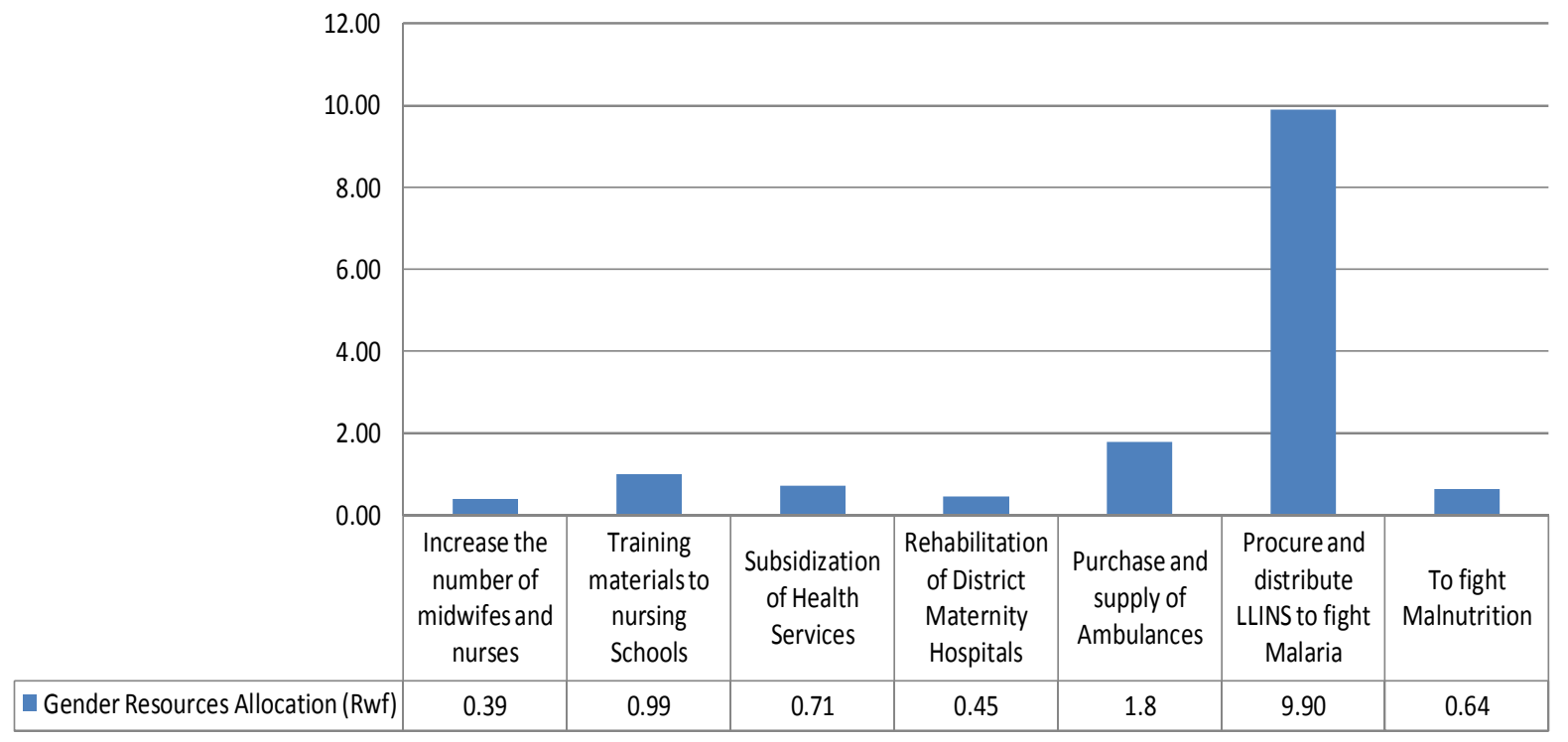

Figure 5. Gender Resources Allocation by MINISANTE2010/2011(Rwf.in Billions).

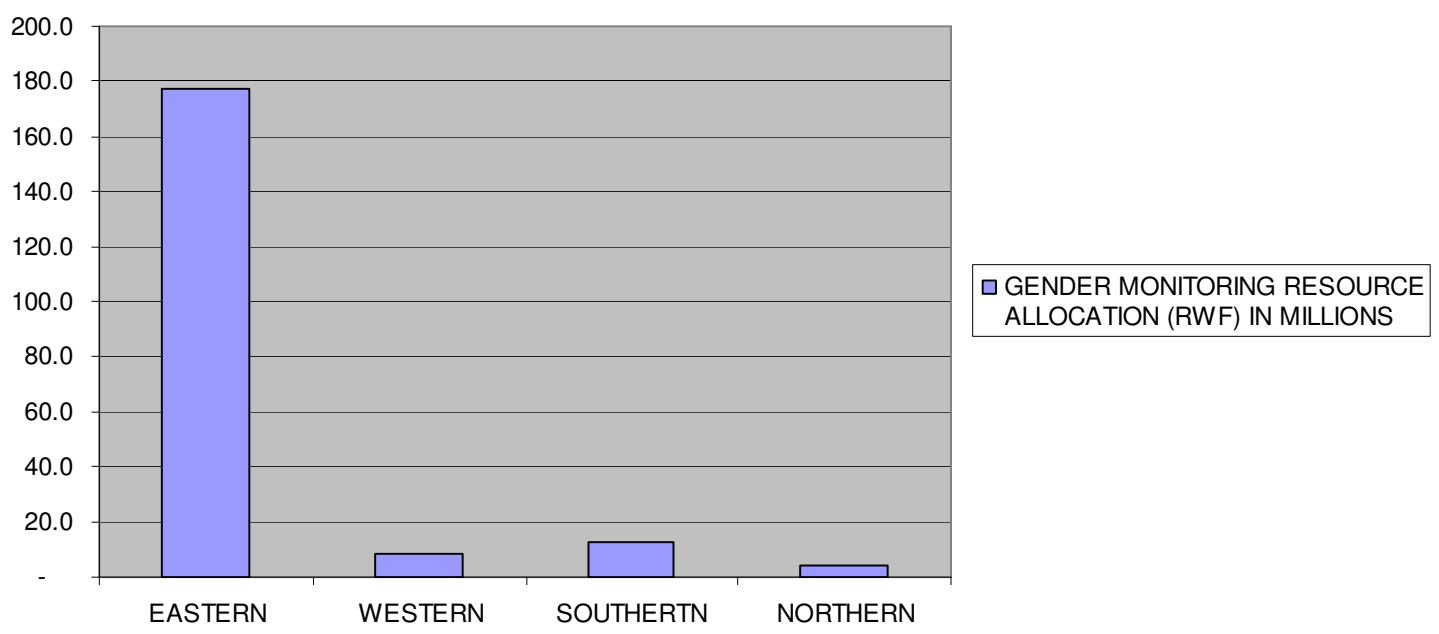

Figure 6. Gender monitoring resource allocation (RWF) in millions.Source: Gender Budget Statement MINECOFIN 2011/2012.

2010 to design GRB curriculum to fast track training of the planners and budget officers in various ministries in Rwanda.

\section{Gender resources allocation by ministry of health at district level}

Health is one of the key pilot sectors where gender responsive budget is being implemented. This research study purposively sampled 15 districts for the purpose of analysis. Among the districts sampled out 12 districts were found to be actively involved in mainstreaming GRB on health. Whereas the three districts do not have any gender resource allocation on health, Figure 6 shows the amount of resources allocated to each district in Rwf in billions, total gender district resources allocation and the percentage of resources allocated to health in relation to the total district gender resource allocation These districts are Ruhango (0.520), Nyaruguru (0.052), Kamonyi (0.091), Huye (0.014), Gesagara (1.076), Ngoma (0.029), Bugesera (1.262), Nyagatare (0.014), Rwamagana (0.012), Kicukiro (0.0351), Kirehe (0.0043) and Gasabo (0.046). This research study established that Bugesera district has entirely allocated all the gender resource allocation to the health sector which translates to $100 \%$ of the total district gender resource allocations. The district with the least gender resource allocation is Nyagatare district with just $1 \%$ of the total district gender allocation (Figure 7). 


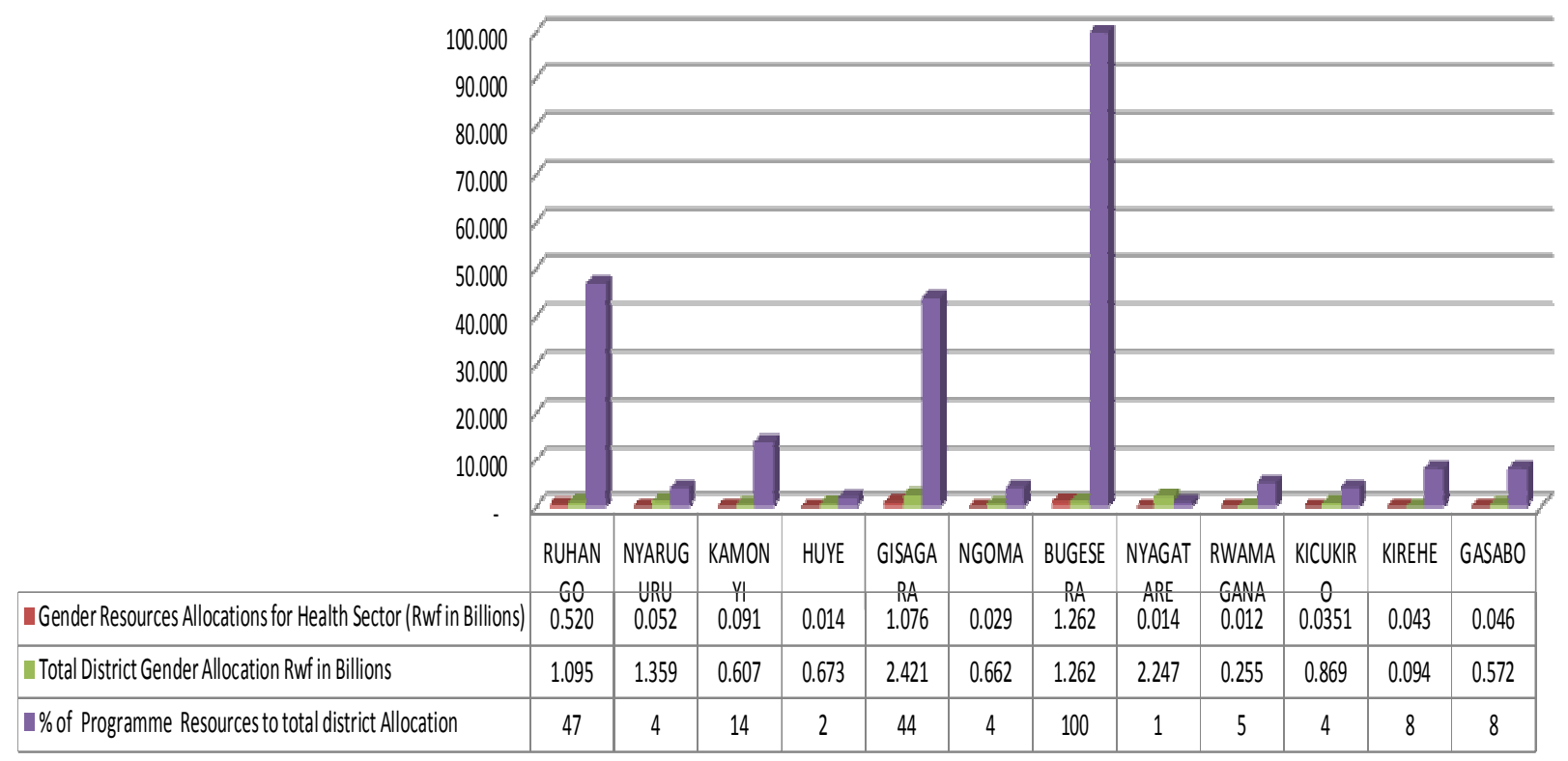

Figure 7. Micro-level gender resources allocation to health programmes 2010/2011. Source: Gender budget statement MINECOFIN 2011/2012.

\section{Gender resources allocation to agriculture sector at district level}

Agriculture plays a critical role in Rwanda. The livelihoods of over $80 \%$ of Rwanda's population depend directly or indirectly on the agriculture sector and the sector contributes about $40 \%$ to GDP. The government of Rwanda's realisation of this role allocates in each fiscal year reasonable resources to finance programmes that support that sector. In the fiscal year 2010/2011, of the 15 districts purposively sampled for this study, 8 districts had set aside resources to programmes targeting gender. This study noted that the gender budget statements prepared by various districts reveals that NYARUGURU district allocated the highest gender resources to agriculture sector programmes of about Rwf. 0.325 billion which translates to $24 \%$ of total resources of the district. GASAGARA district allocated the least gender resources to agriculture sector programmes amounting to Rwf. 002 billion translating to $0.01 \%$ of total district gender resources (Figure 8).

\section{Gender resources allocation by ministry of education at district level}

The gender situational analysis as reflected in gender budget statements at micro-level (districts) indicates various challenges in education sector. These include high dropout rate among girl child at primary level. It is estimated that about $2.6 \%$ girls and $1.4 \%$ boys drop out at district level. Moreover, there are several cases of undesirable pregnancies and HIV in secondary school.
This is coupled with poor conditions of infrastructure facilities. Other challenges are low numbers of girls registered in science education classes at senior six and low supply of text books and equipments for science laboratory and computers as well. The study noted that the gender budget statements prepared by districts sampled for this study indicates sub-programmes and resources targeting this situational gender challenges in education sector. This study shows that GISAGARA district allocated the highest resources to education programmes targeting girls and boys of Rwf. 1.98 billion translating to $81 \%$ of total resources targeting gender programmes in the district. RUHANGO and GASABO allocated the least gender resources translating to $1 \%$ of the total gender resources in the district. The study also noted that only 12 districts of the total 15 sampled for this study have allocated resources promoting gender initiatives while 3 districts have no gender initiatives in their gender budget statement for the fiscal year 2010/2011.

\section{Conclusion}

The process of engendering Gender Responsive Budgeting (GRB) into national accounting system in Rwanda is a positive step and a reflection of government commitments to ensuring that government resources are efficiently allocated to benefit equitably women and men, girls and boys. From our analysis, this study established that the Gender Budget Statements (GBS) are the key tools utilised for gender resources allocation in Rwanda. These tools provide details of activities intended to be 


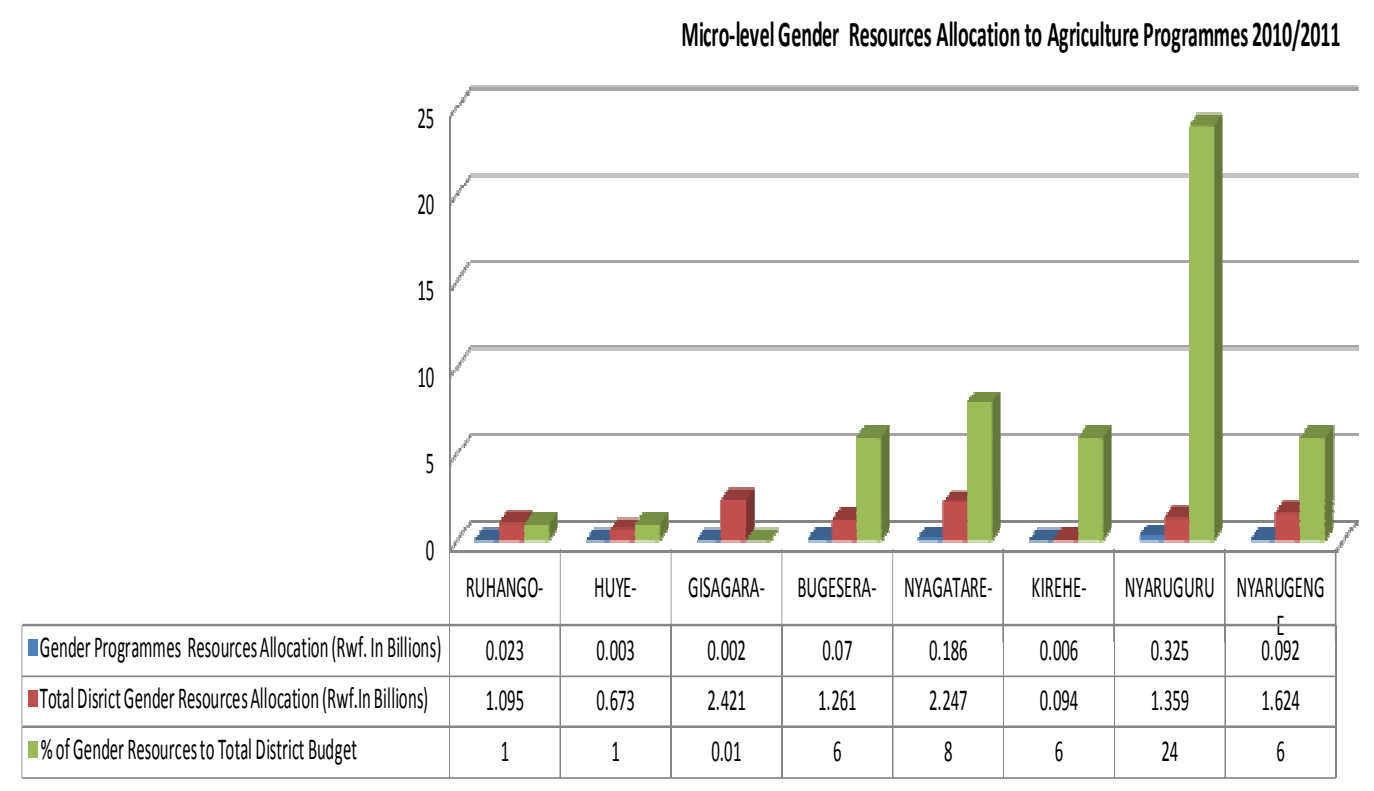

Figure 8. Source: Gender budget statement MINECOFIN 2011/2012.

executed in a programme or sub-programme, input, indicators and development budget allocation (Buchen, 2007). The macro, mezzo and micro analysis on adaptation and integration of GRB into Rwandan accounting system reveals that four key sector ministries were piloted by the government of Rwanda to mainstream budget allocations targeting gender sensitive programmes. This study further reveals that to some extent gender sensitive programmes were well financed at macro-level. For instance the ministries of agriculture and health sector were financed gender resources to the tune of Rwf. 21,385,589,570 and Rwf.13, 062,685,817, respectively. At mezzo-level, the gender budget statements reflected gender resources allocated purposively for internal monitoring and coordination of gender programmes in the country. The magnitude of resources allocated at mezzo level appeared to be lower compared to macro level resources. At micro-level, this study found disparities in gender resources allocation to the 15 sampled districts. For instance, this study indicates two districts that were allocated the highest gender resources namely: GISAGARA (Rwf.2, 421,063,171); NYATARE (Rwf.2, 247, 008,369) while the least financed districts were NYANZA (Rwf. 36, 915.152) and KIHERE (Rwf. $94,922,405)$. The unbalanced resources allocation at all levels but in particular, at micro level raises a concern on the criteria the government of Rwanda has put in place, whether or not there were existing benchmarks against which gender resources were based on. This study further noted that whereas some gender programmes at macro level were allocated resources for implementation in all districts, the same gender programmes were missing in some districts at micro level. This study therefore has a concern on inconsistence of gender programmes implemented which is not in line with resources allocated for gender at macro-level. The other critical issue emerging from micro-level analysis is that there were distortions of information in Gender Budget Statements. The Gender Budget Statements (GBS) are critical tools for gender resources allocation (Das and Mishra, 2006); however, this study established that the tools lacked consistency, harmony and skill in their preparations. For this purposes, this study recommends capacity building on the part of economists, planners and budget officers who are bestowed with the obligation to prepare the GBS tools at all levels. This study concludes that GRB can be a best methodology of engendering public resources using a national budget if and if only transparent bench-marks are set out by governments to guide resources allocation to programmes that target gender perspectives at micro, mezzo and macro-level in a country.

\section{REFERENCES}

Barnett and Grown (2004). Gender Impacts of Government Revenue Collection: The Case of Taxation. Commonwealth Secretariat, Web site: http//www.thecommonwealth.org .Accessed 17 July 2011.

Buchen T (2007) Gender Budget initiatives Uganda, Mozambique and Nicaragua. Vienna. Available at $<$ http://www.genderbudgets.org/index>. Accessed on 24 ${ }^{\text {th }}$ July, 2011.

Budlender D, Elson D, Hewitt G, Mukhopadhyay T (2002). Gender Budgets Makes Cents. Commonwealth Secretariat, London.

Das S, Mishra YM (2006). Gender Budgeting Statement (in India), Misleading and Patriarchal assumptions, Economic and Political Weekly. 29 July 2006.

Elson D (2002). Integrating Gender into Government Budgets within a Context of Economic Reform; in Budlender D, Elson D, Hewitt G. and Mukhopadhyay T (eds.) Gender Budgets Make Cents. London, Commonwealth Secretariat pp. 23-48.

Ichii R (2010) Gender Responsive Budgeting in Education- Advocacy. 
Brief. Bangkok:UNESCO Bangkok.

ILO (2006) Overview of Gender-Responsive Budget Initiatives. A Discussion Paper for ILO staff on the Relevance of Gender-Responsive Budget Initiatives in Promoting Gender Equality in Decent Work Country Programmes.

Ngone DT (2002). Rwanda: Translating government commitments into action Norton, A. and D. Elson. 2002. What's Behind the Budget? Politics, rights and accountability Overseas Development Institute (ODI)

Sharp R (2007b). Gender Responsive Budgets (GRB's). Have a Place in Financing Gender Equality and Women's Empowerment. Expert Group Meeting of United Nations Division for the Advancement of Women, Oslo, 4-7 September 2007. http://www.un.org/womenwatch/ Sharp.pdf (Accessed 20 July 2011).
Sharp R, Vas Dev S (2004). Bridging the Gap between Gender Analysis and Gender- Responsive Budgets: Key Lessons from a Pilot Project in the Republic of the Marshall Islands. (Hawke Research Institute working paper series, No. 25). http://www.genderbudgets.org/ content/view/391/153/ (Accessed 24 JUNE 2011).

Sodani PR, Sharma S (2008). Gender Responsive Budgeting. J. Health Manage. 10(2):227-240.

Villagomez E (2004). Gender Responsive Budgets: issues, good practices and policy options: Regional Symposium on Mainstreaming Gender into Economic Policies Room VII - Palais des Nations, Geneva. 28-30 January 2004 